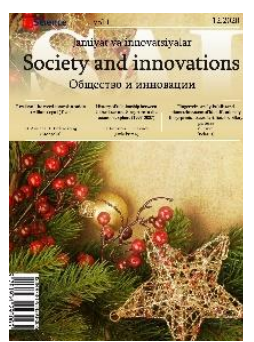

\title{
Improvement of the rules of civil law governing immovable property as objects of civil relations.
}

\section{Nargiza ASHUROVA ${ }^{1}$}

Tashkent State University of Law

\section{ARTICLE INFO \\ Article history: \\ Received September 2020 \\ Received in revised form \\ 15 October 2020 \\ Accepted 15 November 2020 \\ Available online \\ 31 December 2020}

\section{Keywords:}

Immovable property

Ownership

Civil law

Legal regime

Legislation

State register

Buildings

Objects.

\begin{abstract}
This article critically analyses legislative acts concerning the legal regime of real estate of the Republic of Uzbekistan and reviews the improvement of the legal status of real estate. In particular, on the basis of the legal characteristic of immovable property, peculiar aspects of the stay (finding) of immovable property in civil circulation, the priority areas of development of the Civil Code of the Republic of Uzbekistan are moving forward (hereinafter referred to as the Civil Code).
\end{abstract}

2181-1415/C 2020 in Science LLC.

This is an open access article under the Attribution 4.0 International (CC BY 4.0) license (https://creativecommons.org/licenses/by/4.0/deed.ru)

\section{Фуқаролик хуқуқий муносабатлар объектлари сифатида кўчмас мулкни тартибга солувчи фуқаролик хуқуқи нормаларини такомиллаштириш}

\section{Калит сўзлар:}

Кўчмас мулк

Мулкчилик

Фуқаролик хуқуқи

Хукуқий холат

Қонунчилик

Давлат реестри

Бинолар

Объектлар.

\section{АННОТАЦИЯ}

Ушбу мақолада Ўзбекистон Республикасида кўчмас мулкнинг хуқуқий холатига тааллуқли қонун хужжатлари танқидий тахлил қилинган ва кўчмас мулкнинг хуқуқий холатини яхшилаш масалалари мухокама қилинган. Хусусан, кўчмас мулкнинг хуқуқий хусусиятлари асосида, кўчмас мулкнинг фуқаролик муомаласида бўлишининг ўзига хос хусусиятлари, Ўзбекистон Республикаси Фуқаролик кодексини (бундан буён матнда Фуқаролик

\footnotetext{
${ }^{1}$ Candidate of Law, Associate Professor, Independent Researcher of Tashkent State University of Law, Tashkent, Uzbekstan

E-mail. nargiz908@mail.ru
} 
Кодекси) ривожлантиришнинг устувор йўналишлари илгари сурилган.

\section{Совершенствование норм гражданского права, регулирующих недвижимое имущество как объект гражданских правоотношений}

Ключевые слова:

Недвижимость

Собственность

Гражданское право

Правовой режим

Законодательство

Государственный реестр

Здания

Объекты.

\section{АННОТАЦИЯ}

В данной статье критически анализируются законодательные акты, касающиеся правового режима недвижимого имущества Республики Узбекистан, и рассматриваются вопросы совершенствования правового статуса недвижимого имущества. В частности, на основе правовой характеристики недвижимого имущества, особенностей нахождения недвижимого имущества в гражданском обороте выдвигаются приоритетные направления развития гражданского кодекса Республики Узбекистан (далее - Гражданский кодекс).

\section{RESEARCH DESIGN}

When highlighting the importance of real estate as an object of civil turnover and the issues of improving its legislative acts, the methods of analysis, logic, comparative study of national and foreign legislation, description of scientific articles, review of legislative acts and classification of contracts were chosen.

\section{THE PURPOSE OF THE RESEARCH}

Is to analyse the presentation of the legal regime of immovable property in the civil legislation of the Republic of Uzbekistan, specific aspects of stay in civil circulation, legislative norms concerning state registration of immovable property and to develop relevant proposals and recommendations on this basis.

\section{EXPECTED RESULTS}

As a result of the analyses carried out, proposals will be developed to improve the Civil Code of the Republic of Uzbekistan and judicial practice. Reasoning on clarification of elements and requirements of treaties will also be clarified.

\section{ANALYSIS OF LITERATURE}

Issues of legal regime of immovable property, its stay in civil relations and conclusion of transactions casatally of buildings-structures, enterprises as separate real estate objects are very widely analyzed in Uzbek and foreign jurisprudence. In particular, in the monograph of V. Ergashev and N. Imomov entitled "Real Estate Objects", on the basis of the existing legislative acts of the Republic of Uzbekistan, scientific analysis was carried out on the definition of real estate and the legal regime of its objects.

According to the authors, the practice of applying the Civil Code and other legislative acts on immovable property shows that there are sufficient grounds to replenish the list of 
immovable property specified in Part 2 of Article 83 of the Civil Code with a number of new real estate objects.

The need to include them in the list of real estate objects can be explained not only by the fact that these objects are of special importance for civil circulation, but also by the need to further clarify their legal regime. A number of such facilities include buildings (residential and non-residential buildings) and facilities not completed by construction.

D. M. Karahodjayeva analyzes issues of development and improvement of legislation on real estate as an object of ownership of legal entities. In her opinion, the right of ownership in relation to buildings-structures is exercised by a legal entity on the basis of its charter and in this case the management bodies have the right to conclude transactions related to civil turnover of immovable property.

From Yu.B. Saipova studied the legal regime of real estate as a property basis for entrepreneurial activity. In her opinion, as immovable property leading to the emergence of civil relations, the object of natural origin or raw materials or property resulting from work is recognized. The raw material must be individually defined, that is, there may be characteristics, properties or aspects inherent only in the raw material.

According to Christine Quitman, a researcher in the Law and Economics Department at Johann Gutenberg University in Mainz, Germany, in her monograph entitled "Protecting Property and Possession in German and English Law: the comparative and legal analysis of sharp communication between property and possession", if the German ware (property) right is created on the basis of an evidence-based pandektny system, then in the English law which was historically formed on the basis of feudal traditions, the term "real estate" cannot be used in literal sense as this term in a varying degree does not make out economic or other "authoritativeness" of the personality from the thing.

At the same time, as K.Quitmann argues, the term ownership (usually the translation of this term means "property") compared to the term formed in English law, in relation to real estate is interpreted as a status of "convenience" or "excess," as well as in the right to own a thing (better right to possession) the owner exercises his rights not for the interests of the beneficiary, but in his interests.

\section{INTRODUCTION}

The current legislative acts provide for such issues as the concept of real estate, the processing of transactions and rights in relation to them, the rental of real estate, the State registration of transactions concerning real estate, the maintenance of real estate records, and the State cadastral. However, although at first glance it seems that issues and practical problems concerning real estate are solved by this, it is clear that from the theoretical and practical aspect there is still no systemic conceptual approach regarding the definition of the legal regime of real estate. For today, under the influence of advances in science and technology, the description of real estate given in the current legislation also loses its significance and meaning. This is real estate "objects whose movement without disproportionate damage to their purpose is impossible," referred to in part 2 of Article 83 of the Civil Code. Because today, many examples in practice have proved that taking advantage of the achievements of technological progress, buildings and structures that are real estate objects can be moved from one place to another and this rule has almost disappeared.

In addition, in determining the legal regime of real estate, the justification for a natural property, that is, the fact of an inextricable link with land, can now also be assessed as an 
unjustified approach. However, the fact that part 3 Article 83 of the Civil Code provides that "other property may be included in real estate in the law" and, in practice, is based solely on its natural nature, also creates problems in the legal regulation of this area. It is therefore necessary to apply the practice that the legal regime of a property may be defined by law as immovable property provided for by the legislation of foreign countries. The circle of such objects, has to be presented accurately and clearly, but not in such open and abstract look as it is specified in part 3 of Article 83 of the Civil Code.

In most cases, there is no legal definition in relation to the conditions of existence of real estate and its integral part of the land plot in the Civil Code. Yes, today in the Land Code the concept of a land plot is given. However, even under the assumption that the Civil Code regulates civil relations related to real estate, it would be advisable to bring this definition to the Civil Code.

In the current civil law, special rules regarding the application or non-application of civil law on things with respect to real estate are not provided. Regulation of civil transactions regarding real estate without providing an accurate description of real estate objects, not determining their place in the general system of civil law objects leads to certain difficulties.

Also, the current legislation did not reflect the features of the exercise of property rights in relation to buildings, structures and other real estate. For example, in the current legislation, the demolition of buildings and structures and their legal consequences are not provided. It must be pointed out that in such cases, the owner of the building or structure has the opportunity to restore the demolished property, while retaining his rights in relation to the land.

It must be recognized that there are definitely contradictions between the legislative norms governing property relations regarding land plots and the buildings and structures located on them and the rules governing the treatment of these real estate. According to the current legislation, these objects, on the one hand, are considered as real estate objects independently participating in civil transactions, and on the other hand, as real estate objects interconnected both legally and physically. In particular, the difference in the legal regulation of the civil circulation of land and buildings within the framework of property rights in relation to land and the buildings and structures located on them, the disagreement and inconsistency in the regulation of the civil turnover of land and buildings and structures located on them leads to a number of problems.

Such circumstances may arise when the owner of the land plot and the owner of the real estate are completely different individuals. The current legislation establishes rules on the use of certain property rights in such cases. In particular, part 2 of Article 483 of the Civil Code provides "if the terms of use of the relevant part of the land plot by the contract for its sale are not defined, the seller retains the right of restricted use (easement) of the part of the land plot occupied by real estate and necessary for its use in accordance with its purpose." However, this rule is very general and does not reflect conceptual issues of the use of property rights classified as civil real estate claims.

The formation and development of an economic system based on the laws of the market requires the restructuring of property relations on a new basis, the elimination of the pre-existing monopoly on public property, the guarantee of freedom of economic activity, the expansion of private property. Trends in the economic development of the state can be predicted depending on how the issue of ownership is resolved in it. 


\section{General Rules on Real Estate}

\subsection{Description of the definition of "immovable property" in legislation}

Part two of Article 83 of the Civil Code provides a general description of the definition of "real estate". During its development, several legal and technical methods were applied: according to the second part of Article 83 of the Civil Code, land plots, subsoil and perennial plantings are recognized as directly involved in real estate. By their natural origin, these objects are considered immovable property; in relation to other objects which, in accordance with their natural properties ("by nature") are immovable, a typical list of such objects (buildings, structures, curing, perennial plantings) is issued and the criteria are indicated (property is inextricably linked to the land, that is, objects that cannot be moved without causing disproportionate damage), allowing to determine whether the property is considered immovable in a particular situation; according to the law, the real estate regime applies to a number of objects that are movable objects in accordance with their natural properties. Since the natural properties of a number of objects do not allow the general criteria related to land to be applied to them, in the third part of Article 83 of the Civil Code it is indicated that other property may also be classified as immovable. Currently, such property includes, for example, enterprises (Article 85 of the Civil Code) and condominium (Law of the Republic of Uzbekistan "On Partnerships of Private Home Owners").

Assessment of the current legislation. The definition of the concept of real estate provided for in Article 83 of the Civil Code, in accordance with its inherent natural features, is more universal. As the existing legal doctrine and judicial practice show, in the definition of real estate given in the current legislation "objects whose movement is impossible without disproportionate damage to their purpose", it can be understood that there are two specific criteria that the object must meet. At the same time, the inextricable connection of the object with the earth must be understood as a condition for its intended use and this turns this feature into the main criterion. In addition to the specified criterion, according to the conditions specified in Article 188 of the Civil Code, the ownership of citizens and legal entities on land plots arises in cases, in the manner and on the conditions provided by law.

The modern level of development of science and technology allows you to move any objects (such as bridges, residential and non-residential buildings) from one place to another, with the exception of land or plots on which underground wealth is located. However, after moving from one place to another, such objects can be classified as immovable things only if their physical and legal connection with the land is restored and maintained.

Proposals on improving the legislation in force. There is no need for a serious review of the second part of Article 83 of the Civil Code. However, in this case, one cannot ignore the fact that there is a difference in the Russian and Uzbek versions of this norm. At the same time, there are also no grounds for introducing an additional attribute in the description of the term of real estate - that property must be registered in the state register. The requirement to conduct state registration of real estate is not a characteristic of this category of things, but rather its consequence.

In current legislation, the issue of state registration as an element of the legal regime of real estate is resolved by determining the conditions for state registration of property rights to real estate (Article 84 of the Civil Code). This approach is consistent with internationally accepted practices. In addition, its consistent feature found its evidence in solving the problem of recognition of property rights that arose before the entry into force of the Regulation "On 
the procedure for state registration of rights to real estate and transactions with them" approved by Cabinet of Ministers No. 1 of January 7, 2014.

\subsection{Application of the general rules of civil law on property in relation to real estate}

In the current legislation there is no special rule on the application or non-application of property or civil law rules in relation to real estate. At the moment, the regulation of real estate turnover requires the definition of an accurate classification of these objects, their place in the general system of civil law objects.

\section{Proposals on improvement of legislation:}

1. Real estate is always considered to be a subject of certain private features. This feature of it can be commented on by the inextricable physical and legal connection between the property and the land. In this regard, even typical buildings, structures, residential and non-residential buildings, after being tied to a specific land plot, acquire a feature defined by private features. Naturally, a land plot is always considered to be objects with certain private features.

2. Each immovable property shall be an independent and individual object of civil law. Consequently, a complex object that combines objects identified by characteristics characteristic of the type in accordance with the sign of one-time use can be recognized as real estate (for example, an enterprise) if the objects included in it have the characteristics provided for in Article 83 of the Civil Code.

3. If real estate by its natural properties (physical, constructive, etc.) can be divided into several independent objects, then the division excludes the existence of the previous real estate and creates two or more independent objects of legal relations. In this case, registration of the right for each new property is required. At the same time, the registration of rights to previous objects is also carried out. This circumstance must be distinguished from a situation in which certain indicators of real estate have changed (size, internal structure, etc.). In this case, the right to the item remains unchanged, however, the right to real estate must be entered in the Unified State Register regarding the description of the item being the object of law. The need to make changes to the record can be explained by a change in the specific features of the facility and the need to comply with the requirements for the authenticity of the records in the Unified State Register of Real Estate Rights.

4. In cases of recognition of an immovable property as an indivisible thing (part two of Article 88 of the Civil Code), even if a common property right arises, indivisible real estate retains its value as an independent and separate object of civil law. With this in mind, from the second part of Article 85, the second part of Article 488 of the Civil Code, the Land Code, it is necessary to exclude (remove) instructions on the possibility of concluding transactions for the sale, exchange, gift, lease, pledge and distribution of a part of a single immovable property. In cases of the emergence of a common right of ownership of real estate, it may be a matter of transferring to another person a share in the common property right.

\subsection{The definition of the range of real estate to be transferred in Article 83 of the Civil Code. \\ An analysis of the practice of applying the Civil Code and other legislative acts regarding real estate shows that a number of objects listed in Article 83 of the Civil Code do not meet the}


criteria for real estate and therefore they should be excluded from this article and, conversely, it would be advisable to fill out the corresponding list with a number of objects.

Proposals on improving the legislation in force:

1. Perennial plantings should be excluded from the list of real estate objects specified in Article 83 of the Civil Code. In this situation, real estate is not considered perennial plantations, but the land plots on which they are located. The exclusion of perennial plantings from the list of real estate does not mean that the land on which they are located will no longer be considered real estate.

2. The practice of applying the Civil Code and other legislative acts regarding real estate provides sufficient grounds for replenishing Article 83 of the Civil Code by indicating (linking) a number of new real estate objects. The need to add them to the list of immovable things can be explained not only by the fact that these objects are of particular importance for civil circulation, but also by the need to further clarify their legal regime (status). Such objects include buildings (residential and non-residential buildings) and objects not completed by construction.

3. The recognition of a company as real estate (Article 85 of the Civil Code) poses many problems. In this regard, it is proposed to exclude from the article 85 of the Civil Code a description of the enterprise as a property. Instead, it is proposed to supplement Article 91 of the Civil Code with a reference to a complex object - a complex of real estate. The nature of the circulation of this type of objects (gas stations and power plants, pumping stations, etc.) is not in doubt. To be recognized as real estate, the complex must meet the criteria for real estate, as enshrined in Article 83 of the Civil Code. The unification of a single economic goal of objects determined by the characteristics peculiar to the species may become a special individual feature of the complex.

\subsection{Limitation of cases of common equity ownership of real estate}

Since the scope of the grounds for including property in the common property of two or more persons is practically unlimited by law (part four of Article 216 of the Civil Code), property owners are sometimes dishonest in their use of their rights. They voluntarily divide the ownership right into "small" shares (for example, 1/100,1/32) and transfer them to other persons, thereby creating countless owners of common property. Such actions are often carried out in relation to real estate, such as residential buildings and land.

Proposals on improvement of legislation. Considering the above, it is proposed in Article 216 of the Civil Code to introduce a norm restricting the possibility of allocating, for the purpose of subsequent issuance to another person, a share that does not correspond in another form to the principle of survivability, an inadequate or allocated share by the norm defined by law according to own measurements in the ownership of the owner of a house, land, etc. . This restriction should not apply in cases where the right of common ownership arises against the will of the owner (inheritance by law, etc.), since in such cases the owner does not abuse his right.

\section{Special rules on certain types of real estate}

\subsection{Legal regime of an object not completed by construction}

Current legislation and its assessment. Prior to the adoption of the Regulation "On the procedure for state registration of rights to real estate and transactions with them", the issue of recognition of objects not completed by construction became the subject of heated discussions. According to paragraph-5 of the said Regulation, objects not completed by 
construction are buildings and structures, the construction of which has begun on the allotted land in the prescribed manner in accordance with the approved project documentation, but by a certain day has not been completed or completed by construction, but not accepted for operation by the state commission objects and the acceptance certificate of which is not approved by the decision of the hokim (mayor) of the corresponding district (city).

Proposals on improving the existing legislation:

1. In our opinion, it is advisable to include objects not completed by construction in Articles 83 of the Civil Code, that is, in the standard list of immovables. Since this reflects the importance of the stay of these objects in circulation.

2. The legal regime of objects not completed by construction should be determined on the basis of the following approaches: ownership of the object not completed by construction belongs to the owner of the land plot, to the person who has the right to lease the land plot, to the person who owns the land on the basis of the property right; therefore, it does not matter if the property was built by the owner (owner) of the land on its own or as a result of the execution of a construction contract; since the owner of the constructed object is the owner (owner) of the land, it does not matter whether the contract for the construction contract was terminated.

3. The very need for state registration of ownership of an unfinished construction object arises from the owner (owner) of a land plot only in case of suspension of construction. The basis for state registration of ownership of an unfinished construction object is a document on the ownership of the land or transfer of land with one of these rights. State registration of property rights also requires the issuance of a building permit in order to prevent cases of state registration of property rights to an unauthorized object (Article 212 of the Civil Code).

4. In view of the foregoing, amendments should be made to $\S 3$ "Building Contract" of Chapter 37 of the Civil Code. In particular, the contractor carrying out the construction at the expense of its own materials remains the owner of such materials until they are used in construction. From the indicated time, the contractor's ownership of the transferred materials is terminated in connection with the destruction of the materials themselves from the legal aspect. This does not mean that the customer becomes the owner of the materials. Materials, from the moment of their legal destruction, cannot be in circulation in their previous state. And the customer becomes the owner of the construction object (not completed by the construction of the object), during the construction of which these materials were used.

\subsection{The legal regime of the technological complex of the enterprise and real estate}

Current legislation on the enterprise as real estate object. In accordance with Article 85 of the Civil Code, the enterprise as a whole as a property complex is recognized as real estate. The structure of the enterprise as a property complex includes all types of property intended for its activities, including land, buildings, structures, equipment, inventory, raw materials, products, the right to claim, debts, as well as rights to designations that individualize the enterprise, its products, works and services (company name, trademarks, service marks), and other exclusive rights, unless otherwise provided by law or contract.

In general, an enterprise is recognized as real estate as a property complex. It is in this capacity that an enterprise or part of it can be the object of sale, pledge, lease and other transactions related to the establishment, amendment and termination of property rights. 
The right of ownership and other property rights to real estate (the occurrence, transition, restriction and termination of these rights) are subject to state registration in the manner prescribed by the Regulation "On the procedure for state registration of rights to real estate and transactions with them". State registration of rights to an enterprise as a property complex and related transactions is carried out by authorized bodies for registration of rights at the place of registration of an enterprise as a legal entity. The right to an enterprise registered as a property complex is the basis for entering into the Unified State Register of rights to real estate at the location of the object of records for each real estate included in this company.

\section{ASSESSMENT OF CURRENT LEGISLATION}

1. The lack of clear features of the enterprise as an object of civil rights, allowing to distinguish it from other property complexes that can be used in entrepreneurial activity should be recognized as the main drawback of the current legislation. The situation is aggravated by the dispositive nature of the norm on the composition of the property of an enterprise. In addition, in the definition of the concept of an enterprise, the main emphasis is on the property factor, and elements of the enterprise, such as work, business, are of secondary importance. Recognition of the enterprise as being inherent in real estate does not solve the problem, but rather puts it in second place.

2. Special rules for state registration of rights to an enterprise are not free from internal contradictions: on the one hand, the rights to certain real estate in the enterprise and transactions related to these objects must be registered at the location of the respective objects; on the other hand, the right to a registered company is considered the basis for making entries in the register of rights to each object that is part of the company.

3. Civil legislation related to the company is regulated in the existing legislative acts, in particular, sale, leasing, trust management, mortgage. However, the legal regulation of various transactions is not characterized by uniformity:

a) with regard to determining the composition of the enterprise;

b) with regard to determining the form of the transaction (here it is sufficient to compare Articles 490-491 of the Civil Code on contracts for the sale of an enterprise and Article 580 on an enterprise lease agreement);

c) in relation to the protection of the rights of creditors for obligations entered into the enterprise: when renting an enterprise, the rights of creditors for obligations are limited to setting the lessor to terminate or early fulfill his obligations and recover damages (part two of Article 579 of the Civil Code); upon sale of an enterprise, the rights of creditors for obligations entered into the enterprise are ensured by granting them the right, within three months from the day of receipt of the notice of sale of the enterprise, to demand from the seller: termination or early fulfillment of obligations and compensation for losses, or recognition of the contract as invalid in full or in the corresponding part ( Part Two of Article 492 of the Civil Code). In addition, after the transfer of the enterprise to the buyer, the seller and the buyer are jointly and severally liable for the debts included in the transferred company, which were transferred to the buyer without the consent of the creditor (part four of Article 492 of the Civil Code).

\section{Proposals for amendments to civil law:}

1. In the interests of property circulation, an enterprise (property complex used in entrepreneurial activity) may be recognized as a separate type of property, as well as an independent object of civil and civil law transactions, however, the enterprise should not be 
assessed as real estate. An enterprise may include (or not include) real estate, as well as the right to own immovable property ("immovable property within the enterprise"). For this, it is necessary to more clearly define the characteristics of the enterprise, which should be understood as the enterprise, the existing property complex used by the owner in entrepreneurial activity.

2. Since the enterprise is not considered immovable property, the rights to the enterprise, the restrictions on them and the duties imposed on them, their occurrence and termination are not subject to state registration. The public nature of transactions concluded with enterprises as a necessary guarantee of the rights and legitimate interests of creditors and other participants in a property transaction is ensured in another way - by compulsory announcement of transactions concluded with the enterprise.

The conclusion of a transaction on the transfer of the enterprise to another person should mean that the right to the corresponding property complex is registered with the right holder transferring it to another person and this right passes to the buyer.

After the conclusion of such a transaction, the company loses its importance as a separate object of property rights, and the buyer is recognized as the owner and copyright holder of certain types of property, respectively included in the structure of the enterprise. Only the transfer of ownership of real estate within the enterprise and the imposition of obligations on them are subject to state registration. At the same time, the simplified registration procedure provided for at the company and related transactions can be maintained, or the issue of reducing the state registration fee for the transfer of rights to each property sold as part of the property of the enterprise should be resolved.

3. The Civil Code (in Article 85 or as a separate article) should describe the general rules regarding all transactions related to enterprises (sale, rental, trust, mortgage, gift), in particular: on the procedure for determining the composition and value of property of an enterprise (including claims and debts); inform lenders and their rights; on the procedure for transferring the enterprise; on state registration of transfer of rights (imposition of obligations), etc. In this case, in the paragraphs and chapters of the Civil Code devoted to certain types of contractual obligations, only those special rules should be retained that arise from the nature of the respective obligations in other laws. In particular, taking into account the new characteristic of the enterprise as a separate object of civil rights, the legal regulation of the mortgage of the enterprise can be supplemented by the rule according to which the mortgage of the enterprise is allowed only if the enterprise has an object (s) of real estate or a right to lease real estate property. If immovable property is withdrawn from the company, the mortgage must be considered invalid, and the rest of the property included in the company in accordance with the law should be recognized as a pledge. In the case of a pledge of an enterprise that does not contain real estate, a pledge agreement must be drawn up in accordance with the rules similar to the pledge of goods in circulation; it will be appropriate to introduce for the tenant a rule applicable to the lease of enterprises prohibiting the transfer to another person or other disposal of the leased real estate within the enterprise; the rules for the lease of enterprises (in the relevant part) may also apply to relations arising from an enterprise trust agreement.

4. The legislative acts should also specifically regulate a special object of civil rights the technological property complex. The following may be recognized as necessary features of this special object of civil rights: 1) a combination of various objects of movable and immovable property with their common economic value; 2 ) the presence of a land plot as part 
of the technological property complex (rights to the land plot) where the object (s) of real estate located in the complex is located. The technological property complex is a complex thing (Article 91 of the Civil Code). Transactions related to technological property complexes may be subject to certain rules regarding transactions related to enterprises (for example, the rules on state registration of transfer of ownership) and this would help simplify the property circulation of real estate included in the technological property complex.

\subsection{Legal regime of residential and non-residential premises of a building}

In the current legislation, both residential premises (Articles 169, 171 of the Civil Code and others) and non-residential premises (Regulation "On the procedure for state registration of rights to real estate and transactions with them") are considered as an independent type of real estate and civil rights, however such a feature of them is not adequately reflected in the legal regimes of these objects defined by law.

Suggestions for improving existing legislation. Residential and non-residential premises can be recognized as independent objects of civil circulation as simple, indivisible things registered or subject to registration in the Unified State Register of Property Rights or Real Estate Rights. One of the serious difficulties in determining residential and nonresidential buildings as independent real estate objects is manifested in the issue of determining the spatial boundaries of such objects (this is necessary to describe them as things). The main legal (legal) principle used in determining the spatial boundaries of a property is the principle of the ability of such an object to be in independent civil relations. The legal characteristic of any thing includes a reference to subjective civil rights (that is, the ability of a thing to be in a civil relationship) that either exists or can exist in relation to such a thing. Therefore, in the sense of civil law, real estate can be property, the rights to which are registered or can be registered (to be registered) in the "Unified State Register of Rights to Real Estate".

The descriptions given in accordance with the terms "building" and "premises" do not apply to the subject of civil law, however, descriptions of these terms should be indicated for this Concept. Although there is no definition of the term "premises" in the current legislation, the term "premises" is used in a number of articles of the Housing Code (Articles 32, 33, 35, 42, etc.). Typically, a premise is a separate unit in the property of citizens or legal entities, public structures (part of a residential building, real estate object connected with the residential building), intended for independent use for residential, non-residential or other purposes. And the concept of a building is provided for in the Town Planning Code, according to Article- 2 of this code, a building is a building system consisting of load-bearing, enclosing or combined structures that form an enclosed space designed for people to live or stay depending on their functional purpose and for performing various types of production processes.

In contrast to this legal definition, in this Concept, the term building (structure) is understood as being built manually (newly created or adapted), fixed on the ground or underground, the structure recognized in the manner established by law suitable for use for one or another purpose. Depending on the design features and method of use in the building (structure), one or several rooms can be distinguished, that is, inside the building (structure), structurally and spatially separated parts suitable for use can be distinguished. Unlike a building, a room does not have any material expression. 
So, a room is a thing only in a legal sense. On the basis of suitability for life, veins and non-residential premises are distinguished. Requirements for residential premises are established in legislative acts. Therefore, any living space is suitable for independent use. Nonresidential premises are distinguished by premises suitable for independent use and by other types of premises ("office premises"). The recognition of the premises in the building as independent immovable objects in circulation at the same time means the denial of the existence of the building as an independent real estate object. In this case, the building should not be considered as an object from a legal point of view, but only from a technical point of view. Along with the exclusion of the possibility of registering two or more subjective property rights in respect of one thing (a building and its premises), an order should be established providing for the mandatory state registration of property rights for each immovable property put into civil circulation. However, it is permissible to establish such a presumption, according to which the ownership of a building means recognition of the ownership right of a given person to all premises in the building (without making appropriate entries in the unified state register of real estate rights). This presumption may be applicable in cases where the owner of the building used and disposed of separate rooms in it in such a way that it was not possible to transfer them to another person.

Based on the sign of ability to be in circulation, it should be recognized that part of the property cannot be sold, because its legally independent existence, necessary for transferring the property to another person, is determined on the basis of the register. Registration of ownership of a building or land precludes the possibility of registration of ownership rights to a part (premises) of a given plot or building. Property rights to immovable things exist only because they are registered by the state. Therefore, if considered from a legal point of view, the right of ownership (possession) cannot be real estate that can become an unregistered or unregistered object of circulation. The owner of the building, who wants to manage a separate room, must first allocate this room, that is, register his ownership of the room. In this case, the ownership of the building terminates as a result of the legal disappearance of the building itself.

Instead of the right to the building, several ownership rights arise for certain premises, the number and composition of such premises, the owner determines, taking into account technical rules regarding their independent use and their suitability.

The recognition of premises as real estate also requires the settlement of the issue of the legal status of the common property of the building. The following can be attributed to such property: load-bearing and barrier structures, interfloor ceilings, roofs, foundations, engineering structures, as well as common areas (corridors, stairs, halls, etc.) connecting several rooms with each other or with the external borders of the building.

It is self-evident that the common property of a building must be recognized as property ensuring the availability of all premises and it is not necessary that their direct connection with each other is striking. The legal regime of these elements should provide all owners of premises that are movable things, on the one hand, an unconditional opportunity to freely use these rooms in accordance with their functions, and on the other hand, an unconditional distribution of responsibilities for ensuring the proper use of these rooms. In both cases, since we are talking about "unconditionality," the only legal regime that ensures this is the regime of shared ownership.

For owners of certain premises, the establishment of a common shared ownership regime with respect to common ownership in a building has its own characteristics: for the 
ownership of common ownership in a building is inextricably linked to the ownership of the premises in the building and cannot be transferred or belong to another person together with room.

As provided for in Articles 222 and 224 of the Civil Code, such a share cannot be independently circulated, the co-owner is deprived of the right to demand the actual separation of such property, and, as provided for in Article 223 of the Civil Code, the owner of the premises is deprived of the right to demand the purchase by other owners of his share in relation to the premises; a share in the right to common property does not bind the owner of the premises when disposing of the premises belonging to him with common property, because he does not create a preferential regime for its acquisition by other owners; all obligations and threats related to the maintenance of the building (common property of the building), its accidental damage or accidental destruction lie with the owners (as long as they are the owners of individual premises). In the event of the destruction of the premises, for example, as a result of damage to the upper floor due to natural disaster, dismantling or other circumstances, it should be considered that the former owners of the destroyed premises lost their ownership rights in relation to such premises (the exception is when such premises were restored in a timely manner and in compliance with technical norm). At the same time, in relation to such persons, the right of common ownership to the common property of the building is also canceled. The costs of maintaining common property are distributed among all owners in shares that are set in proportion to the area (or volumes, or other indicators identical for all owners) of premises belonging to them by right of ownership. When distributing such costs, it does not matter whether these or those owners directly use one or another element of the common property. For example, roof repairs, the failures of which do not threaten the owners on the lower floors of a multi-story building, should be carried out at the expense of all owners in accordance with the distribution of shares in the public property. An owner who refuses to participate in general expenses may be fined, including establishing a legal penalty for late payment of payments to cover general expenses.

It should be noted that any type of common property, including common areas, cannot be considered as independent things, since they are completely deprived of the ability to be in circulation. Consequently, easements cannot be established in relation to such common property, and, of course, there should not be a situation in which certain elements (rooms) in the building cannot belong to some owners of premises on the basis of common property rights. The regime of common property in a building should be more clearly defined on the basis of the following: in any building (apartment building) a certain number of rooms intended for independent use (separately from other rooms in the same building) are used, for each of which is registered or can be registered the right of subjective property, from the point of view of the ability to be in circulation, one can distinguish property that belongs to one of two categories: 1) property considered independent - not real imye items belonging to any person on the property rights; 2) property considered as common property in the building, including structural elements of the building, owned by all owners of the premises in the building on the basis of the rights of common shared ownership. For example, one should exclude the existence of legal regimes allowing the ownership of a water supply system, elevators or other persons. The regime of common shared ownership provided for such facilities should prevail even in the case of other property of the co-owners - the husband and wife belong to them on a joint ownership. 
Important features determined by the limited possibility of circulation of common property are also observed when registering the right of common shared ownership in relation to it. In particular, the composition of entities jointly owning property has no significance for civil circulation, but it is difficult to say the same with respect to the description of the composition of property owned by the right of common ownership. Therefore, in the Unified State Register of Real Estate Rights for this type of property, only the first section should be filled in - a technical description of the property, it must be indicated that the property described is the common property of all owners of premises in the building. The last instruction can be considered as an element similar to the elements of the regime, such as the category of land.

Due to the fact that the problem of the right of family members of the owner of the dwelling (including the former owner of the dwelling) to own and use the dwelling is very widespread, and most importantly, has great social significance, it requires a separate review and solution. In our opinion, when solving the problem, it is necessary to proceed from the fact that from a political and legal point of view, providing family members with the owner of a dwelling, including the former owner of a dwelling, the right to own and use this dwelling is appropriate only in accordance with the need to ensure social protection of certain categories of citizens. Since it is impossible to provide such protection through contract law, the only effective civil law method may be to provide such persons (family members of the owner of the dwelling) with a limited subjective property right with respect to such a dwelling. Such a right should conditionally be called "usufruct housing." As a rule, the usufruct of housing should include two rights: 1) ownership of the dwelling; 2) the right to use the living quarters for residence, including the right to reside of minor children of the owner of the usufruct. The usufruct of housing does not include the right of the owner of the usufruit to dispose of the usufruct of the housing in any way, including leaving it an inheritance by law or transferring it in succession. Usufruct may last longer than the life of the owner of usufruct. The ownership of this right to different family members of the owner of the dwelling should be determined as follows:

Firstly, the usufruct of the husband (wife )'s housing. Since the usufruct of housing is the right to someone else's property, it can only be established in favor of the owner or husband who is not a co-owner of the housing in which the husband and wife live. The usufruct of the husband's (wife's) housing may impose an obligation only on the apartment building where the spouses live (permanently or mainly) and which belongs to the wife (husband) without any rights (except for the right to usufruct). In addition, there should not be any other way (including on the grounds provided for in the marriage contract) to satisfy the husband's (wife's) need for housing owned by usufruct.

Secondly, the satisfaction of the child's housing needs. In accordance with the Family Code, granting a minor the right to live with his parents (father or mother) is one of a number of maintenance obligations of parents in relation to a child. In particular, the child has the right to live together with his parents, with the exception of cases contrary to his interests (part one of article 65 of the Family Code); in the case of separation of parents, the child has the right to live with one of them (Article 75 of the Family Code). It is noteworthy that in the latter case, the place of residence of children is determined by agreement of the parents. The provision of housing for the child to be considered as a way to fulfill child support obligations (in whole or in part) of the person in relation to the child. 
Thirdly, the rights of other family members to the dwelling. The fact that the owner has provided this room for living with family members, in all cases provided for in the Family Code, should also be assessed as the fulfillment of maintenance obligations. In cases where the fulfillment of the maintenance obligation consists in the transfer of property (for use on property rights, etc.), such transfer must be based on appropriate civil law relations. If the owner of the dwelling is a person who has maintenance obligations to a family member to whom the dwelling is allocated, the provision of dwelling for the members of the family of the owner of the dwelling is provided within the framework of the usufruct of housing.

Housing usufruct may belong to the husband (wife), as well as to another member of the family who is not the owner of the housing. An alimony obligation in the form of the provision of housing can be determined by agreement of the parties, and in the absence of such an agreement - by decision of the court, in cases provided by law. Like any subjective property right, housing usufruct must be registered in a single state register of real estate rights and for entering into a single state register of real estate rights it can be considered existing.

According to the general rules, the usufruct of housing should not prevent the owner of the usufruct owner, who is a member of the family, from living in the dwelling along with the usufruct owner. If the owner of the usufruct is not a member of the owner's family, the question of the possibility of the simultaneous use of the premises by the owner and owner of the usufruct should be decided depending on the size of the premises. Establishment of the obligation to keep the usufruct owner of the dwelling used by him, in particular, depending on whether or not to retain the right to use the dwelling independently, the owner of the usufruct should be given the responsibility for the full or partial maintenance of the dwelling. The owner of the usufruct may be obligated to pay current payments, including utility bills, expenses for the current and overhaul of the premises, as well as cover other similar expenses.

The question of the appropriateness of assigning to the owner of the usufruct the obligation to pay (solvency of the usufruct) to use the owner's housing of this residential building deprived of the opportunity to independently use the residential building should also be considered. The grounds for termination of the usufruct of housing are the following: loss of maintenance obligations of the owner, loss of grounds for establishing usufruct (for example, the owner of the usufruct has no other dwelling to satisfy his housing needs) or cancellation of the usufruct by a court decision at the suit of the owner of the real estate due to violation by the owner of the usufruct of the conditions of usufruct. In addition, usufruct can be recalled by agreement of the owner and owner of usufruct, as well as in cases of refusal of the usufruct owner from usufruct.

\section{COONCLUSION}

Based on the analysis, the following real estate features were formed:

1. Real estate is considered to be a legal category, which is things established by a special regime on the basis of their naturalness (land, perennial plantings) or erection as a result of human labor (buildings, structures) or equalization by law. Because, if in the material sense, the concept of real estate primarily means land and the benefits inextricably linked with it, then in the legal sense, the concept of real estate is considered an object of legal relations and regulation trumps on the basis of a separate regime.

2. Real estate is considered to be a thing having peculiar (individual) features. Of course, an individual trait is also considered a state inherent in movable things. However, in 
real estate this sign is specific and is an integral part of any real estate. This circumstance is primarily associated with the registration of any object to which a real estate regime is assigned in each country. Indeed, perennial plantations located in a specific territory are not registered, but since such plantations are located on a specific land plot, they are considered an individual attribute as an integral part of this land plot.

3. Any real estate is considered a separate (single) independent object of civil law. It should not matter if the property is a complex thing or a large complex. In the event that a separate part of the real estate is allocated, its registration is required as an independent civil law object.

4. Real estate is always considered a thing marked by its individual characteristics. This feature of it can be explained by the existing inextricable physical and legal connection between the property and the land. Therefore, typical buildings, structures, residential and non-residential buildings, too, after being tied to a specific land plot, acquire a feature defined by individual characteristics. Naturally, the land is always considered an object marked by individual characteristics.

5. Each property must be a separate independent object of civil law. Consequently, a complex object that combines objects with type-specific features in accordance with the sign of use for one purpose can be recognized as real estate (for example, a complex of real estate) if the items included in its composition contain the signs provided for in the second part of Article 83 Civil Code.

\section{References}

1. Kalinin S.Yu. Civil law regime of real estate // Jurisprudence. 2011. № 3. - p. 31.

2. Rakhmonkulov H.R. Objects of civil law (textbook). - Tashkent: TSUL, 2009. - 20 p.

3. Velichko D.A. Civil-law foundations of entrepreneurial activity in the Russian Federation: author. dis. ... cand. legal sciences. - M .: 2003. p-7.

4. Business law of the Russian Federation: a textbook for undergraduates / otv. ed. E.P. Gubin, P.G. Lakhno. 3rd ed., Revised. and add. - M.: Norma: INFRA-M, 2017. p-156

5. Insider information - important, undisclosed service information of the company, the disclosure of which may affect the market value of the company's securities. These may include: information about the expected change in management and the company's new strategy, preparation for the launch of a new product and the introduction of new technology, successful past negotiations on the merger or repurchase of shares; information on affiliates, etc. may be included until information on tenders is made public.

6. Bandorin A.E. The mechanism of legal regulation of entrepreneurial activity in Russia (issues of theory and practice): author. dis. ... cand. legal sciences. - Saratov: 2011. p-7.

7. Zekker F. Yu. Freedom through competition. Competition through regulation. Reform of German energy law in the light of US energy law experience. Translation from German by H. R. Shamsiev // Energy Law. 2006. No. 1. S. 16-17, 21.

8. Popondopulo V.F. Commercial e (entrepreneurial) rights about: textbook / B. F. Popondopulo. - 3rd ed., Revised. and add. - M .: Norma, 2008. p. -64.)

9. Belykh V.S., Belykh S.V. Constitution of the Russian Federation and the legal basis of entrepreneurial activity // Business, Management and Law. Scientific and practical economic and legal journal) http://bmpravo.ru/show_stat.php?stat=1123. 